\title{
LITERATURE REVIEW : HUBUNGAN INTENSITAS PENGGUNAAAN MEDIA SOSIAL DENGAN KEJADIAN DEPRESI
}

\author{
Salsalina Violetha Br Ginting ${ }^{1}$, Syamsul Arifin ${ }^{2}$, dan Hotma Marintan ${ }^{3}$ \\ 1. Fakultas Kedokteran Universitas Palangka Raya, Palangka Raya, Kalimantan Tengah \\ 2. Departemen Ilmu Kedokteran Komunitas Fakultas Kedokteran Universitas Palangka Raya, \\ Palangka Raya, Kalimantan Tengah, Fakultas Kedokteran Universitas Lambung Mangkurat, \\ Banjarmasin, Kalimantan Selatan \\ 3. SMF Ilmu Kedokteran Jiwa (Psikiatri) RSUD Doris Sylvanus Palangka Raya, Kalimantan \\ Tengah \\ Email : akunsalsaakun@gmail.com
}

\begin{abstract}
ABSTRAK
Latar Belakang: Penggunaan media sosial dapat berhubungan dengan terjadinya depresi. Namun, terdapat beberapa penelitian yang justru membuktikan tidak terdapat hubungan intensitas penggunaan media sosial terhadap kejadian depresi.

Tujuan: Membuktikan kecenderungan pengaruh intensitas penggunaan media sosial terhadap kejadian depresi.

Metode: Penelitian ini berjenis literature review dengan data penelitian berupa data sekunder. Penelusuran data dilakukan menggunakan metode PRISMA, sedangkan sintesis data menggunakan pendekatan SPIDER.

Hasil: Dari 15 jurnal yang di review, terdapat 12 jurnal atau $80 \%$ membuktikan bahwa terdapat hubungan penggunaan media sosial dengan depresi sedangkan, tiga jurnal atau $20 \%$ lainnya membuktikan hal yang sebaliknya, bahwa depresi tidak berhubungan dengan intensitas penggunaan media sosial.

Kesimpulan: Terdapat hubungan intensitas penggunaan media sosial dengan depresi
\end{abstract}

Kata Kunci: Media Sosial, Depresi, Intensitas

\section{ABSTRACT}

Research Background: Social media use can be associated with depression incidence. However, there are several studies proving there is no relationship between the intensity of social media use and the incidence of depression

Objectives: Proving the trend of the influence of the intensity of social media use on depression incidence.

Methodology: The type of this research is a literature review with research data in the form of secondary data. Data tracing was performed using the PRISMA method, while data synthesis used the SPIDER approaches.

Results: Among the 15 journals reviewed, there were 12 journals or $80 \%$ proved that there was a relationship between social media use with depression, while three journals or $20 \%$ proved the opposite, that depression was not related to the intensity of social media use.

Conclusion: There is a relationship between the intensity of social media use and depression.

Keywords:Social media, Depression, Intensity 


\section{PENDAHULUAN}

Gangguan mental dengan ciri-ciri perasaan sedih, perasaan bersalah atau rendah diri, penurunan energi, kehilangan kesenangan ataupun minat, berkurangnya konsentrasi serta gangguan nafsu makan atau tidur merupakan pengertian dari depresi. ${ }^{1}$ Menurut World Health Organization (2017) terdapat lebih dari 450 juta jiwa hidup di dunia dengan gangguan jiwa dengan gangguan depresi berkisar 322 juta jiwa. ${ }^{2}$ Menurut RISKESDAS (2018) di Indonesia penderita depresi terdapat sebanyak $6,1 \%$ dengan total jumah gangguan emosional dengan kisaran $6 \%$ tahun 2013 dan meningkat menjadi 9,8 \% tahun 2018. Hal ini mengakibatkan aktifitas sehari-hari bagi penderita depresi kurang maksimal. ${ }^{3}$

Gangguan depresi bisa disebabkan oleh penggunaan media sosial. Penggunaan media sosial yang terlalu banyak dapat mengakibatkan terjadinya penularan emosi baik yang negatif maupun yang positif walaupun tidak berinteraksi secara langsung. Namun, pada kenyataannya konten informasi yang banyak disajikan cenderung negatif yang berisikan kekerasan, kerusuhan, dan konten yang tidak bermoral. Sehingga hal ini menjadi salah satu penyebab berkembangnya angka depresi di kalangan masyarakat. ${ }^{4}$

Berdasarkan penelitian yang dilakukan oleh Mukti (2016) menunjukkan intensitas penggunaan facebook tidak berhubungan dengan kejadian depresi dengan subyek anak SMA. ${ }^{5}$ Sejalan dengan penelitian yang dilakukan oleh Alsabaani et al. bahwa tidak terdapat hubungan yang signifikan antara penggunaan media sosial dan depresi pada mahasiswa. ${ }^{7}$ Sedangkan menurut penelitian yang dilakukan oleh Handikasari (2017) didapatkan bahwa derajat gejala depresi berhubungan dengan intensitas penggunaan media sosial dengan sampel mahasiswa kedokteran kurikulum modul terintegrasi. ${ }^{6}$ Sejalan dengan penelitian yang dilakukan oleh Aziz (2017) menunjukkan bahwa Semakin tinggi intensitas penggunaan media sosial maka semakin tinggi tingkat depresi yang dialami pada mahasiswa. ${ }^{10}$

Berdasarkan latar belakang diatas, hasil penelitian hubungan antara intensitas penggunaan media sosial dengan kejadian depresi didapatkan dua hasil yang berbeda untuk itu diperlukan melakukan kajian kepustakaan untuk mengetahui kecenderungan hubungan intensitas penggunaan media sosial dengan depresi.

\section{METODE PENELITIAN}

Jenis penelitian yang digunakan adalah penelitian kualitatif dalam bentuk studi pustaka atau literature review dengan desain penelitian menggunakan systematic literature review. Data yang digunakan adalah data sekunder yang diperoleh melalui penelusuran data menggunakan Google Scholar dan Pub Medical Centre. Penelusuran literature nasional menggunakan kata kunci hubungan, penggunaan media sosial, depresi. Sedangkan, kata kunci untuk literature internasional menggunakan kata kunci social media use, depression, relation/correlation.

Penelusuran data menggunakan metode PRISMA, sedangkan sintesis data menggunakan pendekatan SPIDER. Terdapat 17 jurnal yang di telaah, yang terdiri atas sepuluh jurnal nasional dan tujuh jurnal internasional yang memenuhi kriteria inklusi dan ekslusi. Kriteria inklusi yang digunakan terdiri dari rentang waktu publikasi literatur tahun 2015-2020, bahasa yang digunakan adalah bahasa Indonesia atau bahasa Inggris, tersedia teks lengkap dalam format full text pdf, merupakan hasil penelitian asli, penelitian tentang penggunaan media sosial yang berhubungan terhadap kejadian depresi, rancangan penelitian yang digunakan ialah cross sectional, case control dan cohort, dan jurnal dapat didownload secara gratis. Kriteria ekslusi yang digunakan terdiri dari Penelitian yang tidak digunakan pada penelitian ini ialah penelitian kepustakaan (literature review).

\section{HASIL PENELITIAN DAN PEMBAHASAN}

Berdasarkan hasil review terhadap 17 jurnal yang menjadi data penelitan ini, hasil analisis menggunakan pendekatan SPIDER didapatkan bahwa 17 jurnal menyertakan total sampel, penyebab dilaksanakan penelitian, desain penelitian, dan hasil penelitian. Hasil analisis tersebut menunjukkan bahwa sebanyak 13 jurnal atau $76,47 \%$ membuktikan bahwa terdapat hubungan intensitas penggunaan media sosial dengan depresi sedangkan, 4 jurnal atau 23,53\% lainnya membuktikan hal yang sebaliknya, bahwa depresi tidak berhubungan dengan intensitas penggunaan media sosial.

Hubungan antara penggunaan media sosial terbukti di 13 jurnal tetapi tidak seluruhnya menyajikan informasi penelitian secara lengkap. Data korelasi intensitas penggunaan media sosial dengan depresi terdapat pada 5 jurnal $(38,46 \%)$ beserta keterangan memiliki korelasi postif, 2 jurnal $(15,38 \%)$ memiliki hasil korelasi tetapi tidak ada keterangan dan enam jurnal $(46,15 \%)$ lainnya tidak mencantumkan hasil ataupun keterangan. Sedangkan untuk durasi ataupun intensitas penggunaan 
media sosial yang dapat mengakibatkan depresi tidak disertakan secara spesifik.

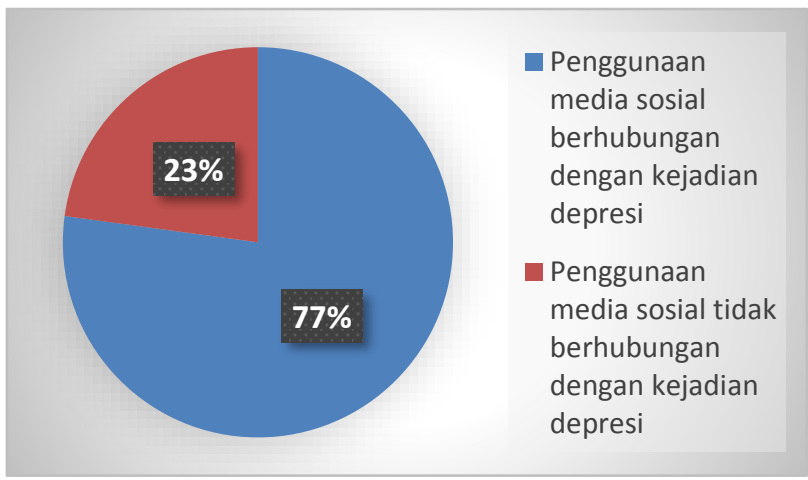

Gambar 1. Presentase jurnal yang menyatakan penggunaan media sosial berhubungan dengan kejadian depresi

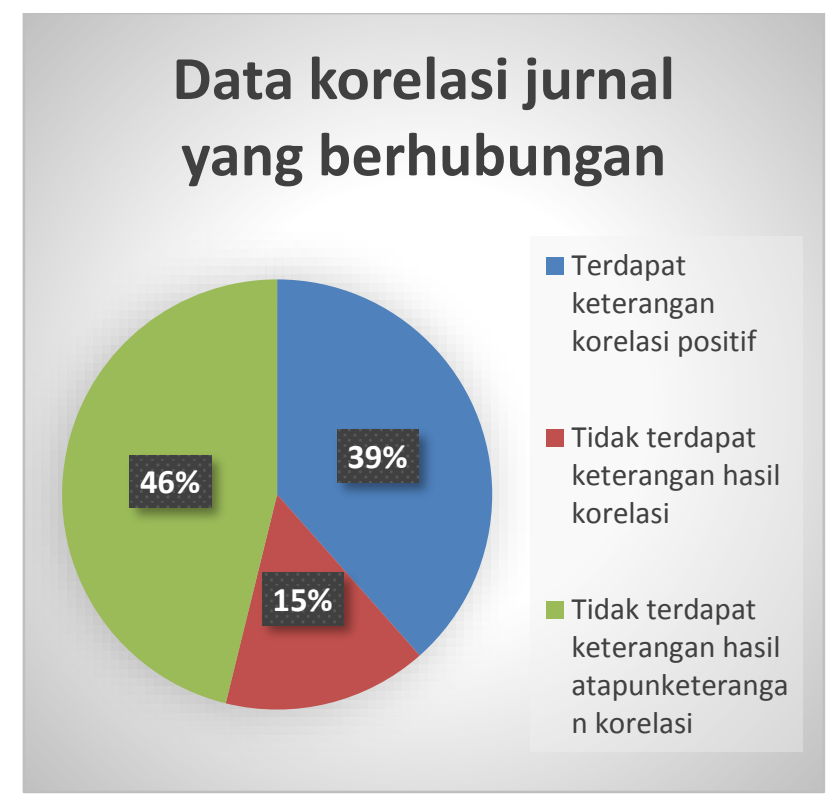

\section{Gambar 2. Presentase korelasi intensitas penggunaan media sosial pada jurnal yang berhubungan dengan depresi}

Data uji validitas dan reabilitas pada kuisioner yang digunakan terdapat pada 4 jurnal $(30,77 \%)$ sedangkan 8 jurnal $(61,54 \%)$ lainnya tidak disertakan uji reabilitas dan validitas data. Rumus pengumpulan sampel terdapat dalam 3 jurnal $(23,08 \%), 2$ jurnal $(15,38 \%)$ menggunakan metode total sampling sehingga tidak menggunakan rumus tertentu sedangkan yang lainnya tidak disertakan. Rumus untuk pengumpulan data disertakan dalam 13 jurnal (100\%) yang berhubungan.
Sedangkan untuk 4 jurnal yang terbukti tidak berhubungan juga tidak menyajikan informasi lengkap pada setiap jurnalnya. Data korelasi hubungan intensitas penggunaan media sosial dengan depresi tidak terdapat pada 4 jurnal (100\%). Data uji validitas dan reabilitas pada kuisioner yang digunakan hanya terdapat pada 2 jurnal $(50 \%)$ dan tidak terdapat di kedua jurnal (50\%) yang lainnya. Rumus pengumpulan sampel disertakan dalam 1 jurnal $(25 \%),{ }^{10}$ dan tidak disertakan di 3 jurnal (75\%) lainnya Rumus untuk pengumpulan data disertakan di 3 jurnal $(75 \%)$ dan tidak disertakan dalam 1 jurnal (25\%).

Hubungan intensitas penggunaan media sosial dengan depresi tidak terbukti dalam 4 jurnal. Melalui penelitian Ali et al, Mukti dan Alsabaani et al, menjelaskan bahwa depresi tidak dipengaruhi oleh faktor penggunaan media sosial saja tetapi dapat juga dipengaruhi oleh perbedaan pada setiap orang dalam Dras, distribusi geografis, kepercayaan agama, begitu juga mungkin dipengaruhi oleh ukuran sampel yang kecil yang menjadi alasan bahwa tidak terdapat hubungan intensitas penggunaan media sosial dengan depresi. ${ }^{5,7,8}$

Penelitian Puukko et al menjelaskan bahwa penggunaan media sosial yang aktif dan berorientasi sosial serta gejala depresi berkembang bersama pada masa remaja. Tingkat rata-rata penggunaan media sosial dan gejala depresi terus meningkat sepanjang masa remaja, tetapi hubungan dalam orang antara penggunaan media sosial remaja dan gejala depresi sangat kecil. Hal ini dipengaruhi oleh jenis kelamin dan status keuangan yang terkontrol dengan baik. Saat ini remaja semakin beralih ke media sosial sebagai sarana utama interaksi dengan teman sebaya. Karena seringnya penggunaan media sosial telah menjadi kebiasaan dalam kehidupan sehari-hari remaja. Sedangkan penggunaan media sosial remaja meningkat ketika mereka mengalami gejala depresi karena mengalami gangguan interpersonal sehingga lebih tertarik pada interaksi media sosial daripada interaksi tatap muka. ${ }^{9}$

Dari jurnal-jurnal yang digunakan dalam penelitian ini, rata-rata peneliti menggunakan sampel yang berusia 13-30 tahun dan paling banyak pada remaja dan mahasiswa baik pada jurnal yang berhubungan ataupun tidak berhubungan antara penggunaan media sosial dengan depresi. Sehingga untuk rentang usia dibawah 13 tahun dan diatas 30 tahun, penulis tidak menemukan jurnal yang berkaitan sampai saat ini. Terjadinya hubungan intensitas penggunaan media sosial dengan depresi dari 13 jurnal yang berhubungan 
disebabkan oleh beberapa hal yang akan dijelaskan sebagai berikut.

Menurut penelitian Al-Aziz ${ }^{10}$ dan Budury et al ${ }^{11}$, depresi terjadi karena adanya sikap membandingkan diri dengan pengguna lain di media sosial yang menyebakan pandagan negatif terhadap diri sendiri atau munculnya perasaan insecure dan menjelekan diri sendiri, dan permasalahan hubungan sosial yang terjadi melalui media sosial. Penelitian Aini dan Apriana ${ }^{12}$ menjelaskan bahwa depresi terjadi karena pengguna media sosial menjadi korban cyberbullying. Akibatnya korban akan merasa rapuh dan sendiri serta merasakan akibatnya dalam jangka panjang dibandingkan tradisional bullying sehingga berdampak buruk terhadap psikologis korban.

Penelitian Jaya et al, ${ }^{13}$ mengemukakan situs jejaring sosial berfungsi sebagai pembentuk kesan. Sehingga respon negatif dapat menimbulkan stres bahkan depresi bagi pengguna. Sedangkan menurut Budury et $a l,{ }^{11}$ depresi bisa dipicu dari berita buruk yang mereka peroleh dari sosial media. Selama pandemi covid-19, media sosial memberikan banyak informasi tentang covid-19, morbiditas dan mortalitas, sementara informasi yang diberikan belum tentu benar dan menimbulkan banyak disinformasi yang justru berdampak negatif bagi pengguna. Banyak netizen yang mengekspresikan perasaan negatif misalnya, ketakutan, kekhawatiran serta kecemasan, hal ini berpotensi memperburuk situasi mental pengguna media sosial yang mengkasesnya. ${ }^{14}$

Hubungan media sosial dengan depresi juga dijelaskan menurut penelitian Zaelani et al, ${ }^{15}$ yaitu penggunaan media sosial game online secara berlebihan akan menyebabkan kecanduan sehingga perkembangan psikososial. Kurangnya interaksi sosial dalam kehidupan nyata dapat mengarah pada emosi negatif terutama pada remaja. Penggantian interaksi langsung dengan komunikasi online dapat mengarah pada depresi. ${ }^{16}$ Ada juga penelitian dari Kelly et al, ${ }^{17}$ gejala depresi terkait dengan penggunaan media sosial dikaitkan dengan kurang tidur, terjadinya pelecehan online dan citra tubuh yang buruk.

\section{KESIMPULAN}

Berdasarkan 17 jurnal yang digunakan dalam literatur review didapatkan kecenderungan hubungan intensitas penggunaan media sosial dengan depresi dari 13 jurnal atau $76,47 \%$ yang terbuktikan sedangkan, 4 jurnal atau $23,53 \%$ lainnya membuktikan hal yang sebaliknya, bahwa depresi tidak berhubungan dengan intensitas penggunaan media sosial.

Terbukanya informasi dari media sosial dapat berdampak negatif bagi pengguna sehingga cenderung membuat pengguna media sosial menyadari banyaknya kekurangan dari diri pengguna yang mengakibatkan perbandingan secara negatif (insecure), mengalami pelecehan secara online, dibully dan kecanduan sehingga interaksi sosial dalam kehidupan nyata semakin berkurang dan menyebabkan masalah psikologis pada pengguna yang dapat menyebabkan depresi.

Sehingga diharapkan dilakukan penelitian lebih lanjut untuk meneliti apa tindakan preventif yang dapat dilakukan agar saat bermedia sosial mengurangi dampak terhadap depresi.

\section{DAFTAR PUSTAKA}

1. World Health Organization. Depression, A Global Public Health Concern. WHO Departemen Mental Health Substance Abuse, 2012; 6-8

2. WHO. Depression and Other Common Mental Disorders. Global Health Estimates. 2017;8-10

3. Kementerian Kesehatan RI. Hasil Utama Riskesdas 2018. Badan Penelitian dan Pengembangan Kesehatan, 2018;102-103

4. Setyawan M. Hubungan antara Durasi Penggunaan Media Sosial dengan Kestabilan Emosi pada Pengguna Media Sosial Usia Dewasa Awal. Yogyakarta. Universitas Sanata Dharma, 2016

5. Mukti R. Hubungan Intensitas Penggunan Facebook dengan depresi pada anak SMA. Jakarta. Program Pendidikan Sarjana Kedokteran, Fakultas Kedokteran. Universitas Trisakti, 2016

6. Handikasari RH, Jusuf I, Johan A. Hubungan Intensitas Penggunaan Media Sosial Dengan Gejala Depresi Mahasiswa Kedokteran (Studi Pada Mahasiswa Kedokteran Tingkat Akhir Yang Menggunakan Kurikulum Modul Terintegrasi). Jurnal Kedokteran Diponegoro, 2018; 7(2): 919-934

7. Alsabaani A, Alshahrani AA, Abukaftah AS, and Abdullah SF. Association Between Over-Use of Social Media And Depression Among Medical Students, King Khalid University, Kingdom Of Saudi Arabia. The Egyptian Journal of Hospital Medicine, 2018;70(8): 1305-1311

8. Ali, S, Al Harbi HA, Rahman SR. Relationship Between Use Of Social Media And Depression Among Female Teenagers In Buraidah, Alqassim, Saudi Arabia. Journal of Child And Adolescent Behavior, 2018; 6(3) 
9. Puukko K, Hietajärvi L, Maksniemi E, Alho K, and Salmela-Aro K. Social Media Use And Depressive Symptoms-A Longitudinal Study From Early To Late Adolescence. International Journal of Environmental Research And Public Health, 2020; 17(16): 5921

10. Al Aziz AA. Hubungan Antara Intensitas Penggunaan Media Sosial dan Tingkat Depresi pada Mahasiswa. Acta Psychologia, 2020;2(2): 92-107

11. Budury S, Fitriasari A, dan Khamida Penggunaan Media Sosial Terhadap Kejadian Depresi, Kecemasan Dan Stres Pada Mahasiswa. Bali Medika Jurnal, 2019; 6(2): 205-208

12. Aini K, Apriana R. Dampak Cyberbullying Terhadap Depresi Pada Mahasiswa Prodi Ners. Jurnal Keperawatan Jiwa, 2019; 6(2): 91-97

13. Jaya SP, Wardani ND, Jusup I. Hubungan Intensitas Penggunaan Situs Jejaring Sosial Dengan Depresi Pada Mahasiswa Tingkat Akhir. Jurnal Kedokteran Diponegoro, 2016; 5(4): 1770-1783

14. Khurshid Z, Waqas A, Ali M and Khaliq $\mathrm{H}$. Association between usage of social media and depression among young adults. Journal of Management Info, 2018; 5(4): 26-30

15. Zaelani AF, Setiawati OR, Lestari SMP. Hubungan Kecanduan Bermain Game Online Dengan Depresi Pada Siswa Smp. Jurnal Psikologi Malahayati, 2019; 1(2): 35-41

16. Liang L, Zhou D, Yuan C, Shao A, and Bian Y. Gender Differences In The Relationship Between Internet Addiction And Depression: A Cross-Lagged Study In Chinese Adolescents. Computers In Human Behavior, 2016; 63: 463-470

17. Kelly Y, Zilanawala A, Booker C and Sacker A. Social Media Use And Adolescent Mental Health: Findings From The Uk Millennium Cohort Study. Eclinicalmedicine, 2018; 6: 59-6 
